\title{
NORTH MACEDONIA IN CONTEXT OF RUSSIA'S HYBRID WARFARE POLICY IN THE BALKANS
}

\author{
SELIM IBRAIMI \\ PhD Candidate Political Science \\ South East European University (SEEU)
}

\begin{abstract}
Russia is growing concern for consolidated democracies and of course the new fragile states of the Balkans. In this

paper I examine the role of Russia in North Macedonia (NM) and the region with emphasis the reaction of the government of North Macedonia in recent years. The research mainly is based in qualitative methodswith analysis of covert operations of Russia in North Macedonia. The research shows that North Macedonia hasn't policy to prevent any future influence ore hybrid war information.
\end{abstract}

Key words: North Macedonia; Russia; hybrid warfare; disinformation; security

\section{Introduction}

Russia cannot accept North Macedonia (N.M.) to be part of Western Military Alliance NATO. Due to the regional rivalries, Russian officials objected the membership of tiny ex-former Yugoslav Republic, now North Macedonia. Two major fronts we may see in next coming years: Eastern Front and the Balkan front as playground for Russia. Ukraine and finally by all indicators including North Macedonia, becomes the flashpoint of rivalry. Political actors in North Macedonia are testing the balance provided by the US for more than two decades. North Macedonia due to the lack of resources has not responded to Russian activities in recent years. The government of the Prime Minister Zoran Zaev has been under systematic pressure by Russian hybrid tactics.

\section{The Gate to the south: North Macedonia, Target of Russia}

The trends of decline in democratic governance continue in the Balkans, and the political events in North Macedonia 2008-2018, were part of the information warfare. Diplomatic efforts to form a new government in North Macedonia after the elections of 2016, raised in that time, some concerns for European Union (EU) and the United States (US) that who will lead the small land lack country.

North Macedonia's integration process towards EU and NATO in that period has stalled, but, after the government was formed in critical situation in 2017, things have change for better for the future of the country and its citizens. Before Prime Minister Zoran Zaev to take power, the security situation in North Macedonia was at lowest point, because the policies of former prime minister Nikola Gruevski, which were against the West.

The people of North Macedonia had no hope that one day the new country will change the course. In2017 in late March the new public poll in North Macedonia published by a private organization's indicated that society is divided regarding preferences for foreign powers. In that time Slavic Macedonian population, favored Russia but the ethnic Albanians were close to the US position. Also, the credibility of EU was at stake. Based in the poll, Slavic Macedonians populationopposedthe EU and the US to get involved in the Macedonian internal affairs. According to the political development, on February 2015, Russian Foreign Ministry announced that foreign services have tried to destabilize North Macedonia.Russian Foreign Ministry supported the former Prime Minister Nikola Gruevski position regarding interceptions, which 'the putsch is organized by the intelligence services of the neighboring countries and by several Western embassies in Skopje'.

Two years after the wiretapping scandal, former Russian Ambassador to Macedonia, Oleg N. Shcherbak met Gruevski again in 2017 to make some efforts for the formation of a new government after the parliamentary elections of December 2016.

Clearly, Moscow with tools of information warfare was attempting to put 'one foot' in North Macedonia. In addition, Russian Foreign Ministry had released dozens of statements on political events in North Macedonia. In the last three years since the wiretapping scandal that led to Gruevski resignation and the formation of new government, Russia has been interested in this part of Southeast Europe, and it engages with political parties in the anti-West campaign, against the policies of the new government of North Macedonia (Bechev,2017). 
In that time diplomats of foreign embassies have played a crucial role. The officials of the US Embassy have denied any attempt to overthrow the government or to isolate the former premier of North Macedonia Nikola Gruevski in early 2017. They also denied the claim that they are pressing political parties to form a majority with the new Social Democrats (SDSM), against the center-right Macedonian political party (VMRO-DMPNE). However, Russian Embassy in Skopje did not share the same opinions.

\section{Kremlin challenges the West}

With its propaganda, during the years 2008-2018, Russia at least demoralized the candidate members of the Western Balkan states towards NATO or EU. Moscow prefers the status of neutrality of countries that emerged from Yugoslav Federation. In other words, Kremlin challenges the West on some levels.

EU and the US have expressed their concerns on several occasions over the direction of democracy in the Balkans, but after the name issue was resolved with Greece, North Macedonia and the regionin some degree is one step close to EU perspective and is getting away step by step from Russian influence (Independent, 2018). Indeed Bosnia, Kosovo, Montenegro and North Macedonia remain on the edge of Russia's 'sharp knife' which has the purpose of reversing the reforms and imposing the set of regulations Kremlin favors' in the Balkans.

\section{Russian Propaganda}

The US investments in the civil society sector since 2008 were not been sufficient to prevent Russian propag anda in North Macedonia. Local analysts have said that the US public diplomacy is challenged, because of Kremlin's involvement in the region and the EU's management policy for the Balkans.

The permanent reactions of the Russian Foreign Ministry were perceived as a support for the anti-US propaganda of the current radical political parties in Skopje. The turmoil in 2017 in North Macedonia was welcome for Kremlin. Russia uses domestic news outlets as propaganda to reach the nations in the region and it wins the hearts of people against the Western approach to some extent. Since 2009, the Russian influence in North Macedonia had been growing, with a capacity to change the decisions of the government and the attitudes of political parties (Washington Post, 2017).

But, The Democratic Union of Integration (DUI) of Ali Ahmeti was 'seen' as a stooge for the Americans to decrease the Russian impact in North Macedonia, but the Albanian opposition had raised some concerns over the ties of the party with Gruevski during the years 2008-2017. Therefore, the tendency of a spread of Russian propaganda remains a threat for the Western Balkans' fragile societies (European Western Balkans, 2018).

\section{Russia's Strategy in the Balkans and in North Macedonia}

Russia's Foreign Ministry, as part of growing activities in the Balkans, has issued several statements on political developments in North Macedonia.

In 2016 in Montenegro was a coup attempt by Russian Intelligence Services to overthrow the government and change the results of elections.

Compared to the EU, the Russian Federation has to a large extent dominated the sphere of information, spreading propaganda around the regionin particular in North Macedonia e.g. via "Russia Today" and "Sputnik".But have the Russians shot at the right point? The epilogue of the growing crisis ended when the leader Zoran Zaev and current PM of North Macedonia really formed the government together with Albanian parties. After the developments of 27 April, former EU High Representative Frederica Mogherini have voiced concerns over developments in North Macedonia, stressing Russia's growing role in the Balkans.

Therefore, in the current geo- political landscape, we see two major geopolitical issues in which the West and Russia are becoming rivals in the Western Balkans.

First, Russia creates a climate that the West gets involved on domestic affairs and the second; the atmosphere paves the way for forces that support Russia.In this race, the Kremlin's involvement surprisingly showed that Russian actions could give the public opinion an opposing attitude.

\section{Background of Kremlin's Economic Activity in North Macedonia}

Russian economic activity in North Macedonia has limited capacities. The geographic location of North Macedonia compared to other Eastern and Central Europeancountries makes the country less vulnerable and indirect Russian military pressure. But proposed business projects, current companies that are already operating in North Macedonia, the proposed system of natural gas delivery, can change possibly in the future the policies of government officials towards the decision-making process and put the country at risk of Russia's influence. 
Based on the report of the Strategic Analysis of Russian Business Activity in North Macedonia, published by the US-based "RWR Advisory Group", in March 2015,

'Story Trans Gas' announced plans to build a $61 \mathrm{~km}$ part of a $96.6 \mathrm{~km}$ gas pipeline in North Macedonia linking Klecovce to Negotino, near the northern border with Serbia in central Macedonia (Rwradvisory,2015).

Secondsection is the construction of the pipeline stretch with the southern border of North Macedonia. Russia's plan was that this pipeline will eventually be linked to the project

The most regional project is "Turkish Stream", which will be used to deliver Russian natural gas to Europe and possibly serve as a driving force against the Western Balkan states. Other prestigious oil companies such as 'Lukoil, which is spread all over the countryman a significant role in the country's fragile economy.

National media in 2011 reported that the Russian corporation 'Prodis', part of the pharmaceutical company 'Protek Group', started its investment in the Macedonian market. Also, Russian investors are interested in agricultural products. Since 2012 Russian investors from the Rostov region are interested in building shopping centers for agricultural products in North Macedonia for Macedonian fruit and vegetables. The two countries, in order to advance trade relations, signed in 1993 an agreement on trade and economic cooperation between the governments of Macedonia and Russia (Balkan Insight, 2018).

Most importantly, North Macedonia's export to Russia marks a record growth of $140 \%$, while Russia's export to North Macedonia is almost 28.7\%. In the third quarter of 2016, Russia's trade with North Macedonia amounted to $\$ 25,930,819$, up $2.70 \%$ ( $\$ 682,641)$ compared to the third quarter of 2015 .

Meanwhile, apart from the international newscasts broadcast in Russian, in North Macedonia, the right-wing Macedonian-language portals continue to report and develop Moscow's propaganda e.g., Infomax.

\section{Western Policy Objectives}

With EU and US dedicated tools for civil society in North Macedonia, from independence until today, a resilient and willing society was not built to fight corruption and the irresponsible leaders. According to analysts, Russian information propaganda in North Macedonia has put the EU-backed civilian bloc and other factors behind.

The US and the EU must find a different approach as far as the growing crisis in regions with frozen conflicts (Kovacevic, 2014).

Apparently, the rift between Americans and Europeans will reflected the public policy execution and fulfillment of diplomatic objectives not only in North Macedonia but also in WB-6 countries. Moreover, the Balkans and North Macedonia remain hot spot that requires a proper and timely administration (Time, 2018)

However, no one had thought that the end of December of 2017 the info war between the American and Russian embassies in North Macedonia, would start with polluted air and end with the issue of supplying Russian gas to North Macedonia.

The Russian Embassy in Skopje launched a virtual 'fight' on Twitter's social network against the US Embassy in Macedonia's post that demanded a proposal for air pollution.

"No" Twitter war "We asked Macedonian citizens to answer a question about the short-term steps for air purification. Another Russian pipeline will not do so. The US supports Macedonia's desire to bring gas to the cities of Macedonia and a variety of gas supplies to Macedonia and Europe "- said in that time the US Ambassador to Macedonia Jess L. Baily, in another post on Twitter.

\section{Hybrid Actions: The Virtual War}

However, a long-term and thought-out plan was implemented by the public diplomacy of the Russian Embassy in North Macedonia. Moreover, the policy of US and Russia for North Macedonia became the new 'virtual war' between two major powers on the nature and importance of natural gas pipelines in the Balkans and the type of governance.

The 'Southern Stream', which was abolished by the Russian government in 2015, is currently reviving the 'Turkish Stream'of natural gas, which aims to supply some South and Central European countries with mixed gas from the Russian-Turkish pipeline.

At the time when former Prime Minister Nikola Gruevski was in power, the Russians were almost completely under the control of North Macedonia's political underground and were in the process of using then the government coalition and its policies for the Kremlin's goals and objectives. Russian policies were aiming for collapse of pro-Western governments and government guarantees that North Macedonia would continue with the same policies against the US and EU standards.

As we pointed early, Russian strategic investments are primarily in the energy infrastructure, the oil market and the news outlet organizations around the region. 
North Macedonia is dependent on gas and trade from Serbia, China and from Turkey for the development of its infrastructure, but in regard to trade North Macedonia carries out the $\mathbf{6 0 \%}$ of its trade exchange with the EU member states.

That makes North Macedonia economically dependent on the EU but, according to the forecasts, Russia will take part in the investments of natural gas, and mining in the future. At the regional level, Turkey, Germany, Austria and Serbia are among the strategic partners of North Macedonia commercially and militarily. This is due to the geographical proximity and cost of transport.

In large scope Russia has increased the degree of early 19-century nationalism in the Western Balkans, and the latest developments indicate that the populism and ethnic nationalism is on the rise in mix composed regions (Foreign Policy, 2018).

However, Russia keeps his hands open and engages with Serbia and the region via the news outlets as "Russia Today" and it utilizes Belgrade as a geopolitical tool to stir the unrest in Northern Kosovo and in future in the Balkans. Furthermore, the Balkans and North Macedonia remain a flashpoint for regional actors and non-state actors. The memories of XIX century, stillplays role in the Balkans and states are changing according to the repositioning of global powers (Telegraph, 2018).

\section{Conclusions}

The government of North Macedonia had no policy or strategic thinking on how to deal with such aggressive policy from Russia and other actors. The government in particular PM Zoran Zaev relayed on support from US and EU member states to prevent Russia to stir ethnic and political unrest in the country. The government in feature should start thinking and implementing no just social policies but in process must take action on problems that require initiatives which will impact the feature of citizen and ethnic groups. The information warfare should be considered as extraordinary by the North Macedonia and Western Balkan governments.

North Macedonia may face hybrid attacks as it faced during 2017 and 2018. North Macedonia's government and security agencies need to adapt with new human intelligence resources and techniques to detect attacks and hybrid initiatives from Russia and non-state actors. Expelling a Russian diplomat in spring of 2018 from North Macedonia does not mean that the state and other countries would not be under covert operations, policies by Russia and interested malign actors. 
ISSN 2661-2666 (Online) International Scientific Journal Monte (ISJM) DOI: $10.33807 /$ monte.202004634 Volume 2. No. 1 (2019): April

\section{References}

Bechev, D. (2017). Rival Power: Russia in Southeast Europe. doi:10.2307/j.ctv1bzfph6

Kovacevic, Filip. (2014). Geopolitics of the Balkans and Beyond: What Do Russia, China, and the United States Want.

European Western Balkans (2018). Russian ambassador warns Macedonia over NATO, PM Zaev responds. Retrieved from:https://europeanwesternbalkans.com/2018/03/31/russian-ambassador-warnsmacedonia-nato-pm-zaev-responds/

Marusic S. (2018). Russian Businessman Denies Funding Macedonia Anti-NATO Protests. Balkan Insight. Retrieved from: https://balkaninsight.com/2018/07/17/russian-businessman-denies-fundingmacedonia-s-anti-nato-sentiment-07-17-2018/

Washington Post (2018). Opinion: Macedonia is a tiny country with a giant Russia problem. Retrieved from: https://www.washingtonpost.com/opinions/global-opinions/macedonia-is-a-tiny-country-with-agiant-russia-problem/2018/09/20/47a674d2-bb6b-11e8-a8aa-860695e7f3fc story.html

Volker K. (2018). Don't Let Russia Get Its Way in Macedonia. Retrieved from: https://foreignpolicy.com/2018/09/28/dont-let-russia-get-its-way-in-macedonia/

Perrigo B. (2018). How the Renaming of a Country Became a Battleground Between Russia and the West. Retrieved from: https://time.com/5415031/macedonia-rename/

The Telegraph (2019). Russia Orchestrating Covert Campaign Wreck Macedonia. Retrieved from: https://www.telegraph.co.uk/

RWR Advisory Group (2015). Strategic Analysis: Russian Business Activity in Macedonia. Retrieved from: https://www.rwradvisory.com/strategic-analysis-russian-business-activity-in-macedonia-abstract/ 